\title{
Penetran Tracheal Injury: A Rakshe Accident
}

\author{
Penetran Trakeal Yaralanma: Bir Rakşa Kazası
}

\author{
(D) Hüseyin Fatih Sezer1, (1) Hakan Dayanır2, (D) Mehmet Yavuz Zıraman3 \\ ${ }^{1}$ Nyala Sudan Turkey Training and Research Hospital, Department of Thoracic Surgery, Nayala, Sudan \\ ${ }^{2}$ Nyala Sudan Turkey Training and Research Hospital, Department of Anaesthesia and Reanimation, Nayala, Sudan \\ ${ }^{3}$ Nyala Sudan Turkey Training and Research Hospital, Department of Otorhinolaryngology, Nayala, Sudan
}

\section{Abstract}

Tracheal injury is a rare pathology, but 30\% of all cases can be fatal and $50 \%$ of those patients will deteriorate in couple of hours and may lead to death. The course of treatment must be scheduled by clinical status and severity of pathology; conservative approaches can be followed for minor injuries but major injuries must be performed for advanced cases. A 36-years-old male patient was referred to our hospital from an external center after suffering from a traffic accident. On physical examination, on the neck, there was an approximately $8 \mathrm{~cm}$ long horizontal incision extending into the left side of the trachea. When the incision in the neck was partially explored, it was seen that the trachea was cut due to trauma to the penetrant. The patient was operated on emergency conditions. The trachea was repaired by suturing using 3-0 polypropylene sutures. The injuries of the thyroid and vena jugularis interna were repaired. The patient was discharged after 2 days of intensive care and 2 days of follow-up. Mortality and morbidity rates of penetrating tracheal injuries higher. Also surprise major artery cuts may also accompany the injury. For this reason, physical examination, radiological findings and bronchoscopy should be performed in early stages for differential diagnosis and should the most appropriate treatment choice prefer for reduce high risks.

Key Words: Penetrating Injury, Trachea, Trauma

\section{Öz}

Trakeal yaralanmalar nadir görülen bir patolojidir fakat \%30 oranında mortal seyreder ve \%50 oranında saatler içerisinde kötüleşerek ölümle sonuçlanır. Tedavinin seyri klinik duruma ve patolojinin şiddetine göre planlanmalıdır; küçük yaralanmalar konservatif yaklaşımla takip edilebilir, ancak ileri olgular için cerrahi planlanmalıdır. Otuz altı yaşında erkek hasta trafik kazası nedeni ile götürüldüğü dış merkezden hastanemize sevk edildi. Fizik muayenesinde boyunda trakea üzerinde orta hattan sola doğru uzanımı olan yaklaşık $8 \mathrm{~cm}$ uzunluğunda horizontal bir kesi vardı. Boyundaki kesi kısmi eksplore edildiğinde trakeanın penetran travma nedeni ile kesildiği görüldü. Hasta acil şartlarda opere edildi. Trakea 3-0 polipropilen sütür kullanılarak dikilerek onarıldı. Tiroid ve vena jugularis interna yaralanmaları tamir edildi. Hasta iki gün yoğun bakım ve 2 gün servis takibinden sonra taburcu edildi. Penetran trakeal yaralanmaların mortalite ve morbidite oranları yüksektir. Ayrıca yaralanmaya sürpriz majör vasküler kesiler eşlik edebilir. Bu nedenle ayırıcı tanı için erken dönemde fizik muayane, radyolojik görüntüleme, bronkoskopi yapılmalı ve yüksek riskleri azaltmak için en uygun tedavi seçeneği tercih edilmelidir.

Anahtar Kelimeler: Penetran Yaralanma, Trakea, Travma

Yazışma Adresi/Address for Correspondence: Dr. Hüseyin Fatih Sezer

Nyala Sudan Turkey Training and Research Hospital, Department of Thoracic Surgery, Nayala, Sudan

Tel.: +249967316287 E-posta: hfs.hfs@gmail.com 0RCID ID: orcid.org/0000-0001-5812-7088

Geliş Tarihi/Received: 05.09.2018 Kabul Tarihi/Accepted: 04.03.2019

๑Telif Hakkı 2019 Ankara Üniversitesi Tıp Fakültesi

Ankara Üniversitesi Tıp Fakültesi Mecmuası, Galenos Yayınevi tarafından yayınlanmıştır.

Yayınlanan tüm içerik CC BY-NC-ND lisansı altındadır. 


\section{Introduction}

Trachea lies between cricoid carthilage and carinae in adults, approximately, ranges in C6-T4 vertebrae. It has a tube-shaped structure with an average the length of 10-13 $\mathrm{cm}$ and diameter of $2.5 \mathrm{~cm}$. Anterior part of trachea composes of C-shaped ring carthilage and posterior part consists of muscular, fibrous and glanduler tissues. It is adjacent to major vascular structures. Tracheal injuries occur, mostly, after a blunt trauma (1). According to the severity, level and localization of clinical injury, course of the patients will go along with minor unnoticed symptoms or much more serious occasions. In penetrating trauma, the clinic is often louder. It is a rare pathology, but $30 \%$ of all cases can be fatal and $50 \%$ of those patients will deteriorate in couple of hours and may lead to death $(2,3)$. Shortness of breath and subcutaneous emphysema are the most common syptoms in tracheal injuries (4). Also, cyanosis, hemoptysis, hoarseness and agitation may occur. After penetrating trauma, the trachea lumen may become associated with the external environment. Pneumothorax, hemothorax and, also, subcutaneous emphysema can be observed by further assessments (5). If the trachea is suspected of being ruptured after the injury, bronchoscopy becomes essential for differential diagnosis. The course of treatment must be scheduled by clinical status and severity of pathology; conservative approaches can be followed for minor injuries but major injuries must be performed for advanced cases.

\section{Case Report}

A 36-year-old male patient was referred to our hospital from an external center after suffering from a traffic accident. On physical examination, the patient was dyspneic and tachypneic, the tension was stable and the pulse was tachycardic, $\mathrm{SpO}_{2}$ was $94 \%$. On the neck, there was an approximately $8 \mathrm{~cm}$ long horizontal incision extending into the left side of the trachea. There were also cuts extending to the left side of the face at the deepest point of the skin and subcutaeous tissue in different sizes. There was wheezing during respiration and air leakage by coughing from the cut positioned in the midline of the neck. When the incision in the neck was partially explored, it was seen that the trachea was cut due to trauma to the penetrant (Figure 1). Laboratory findings did not reveal any pathologic value other than partial hemoglobin decrease. Thorax computed tomography showed that trachea integrity was lost in the anterior portion of the proximal trachea (Figure 2). The patient was operated on emergency conditions. During the operation, it was observed that the cartilage portion of the trachea was severed completely and membranous portion was ruptured at $1 / 3$ of from the right side. The trachea was repaired by suturing the membranous parts continuously and the cartilage parts

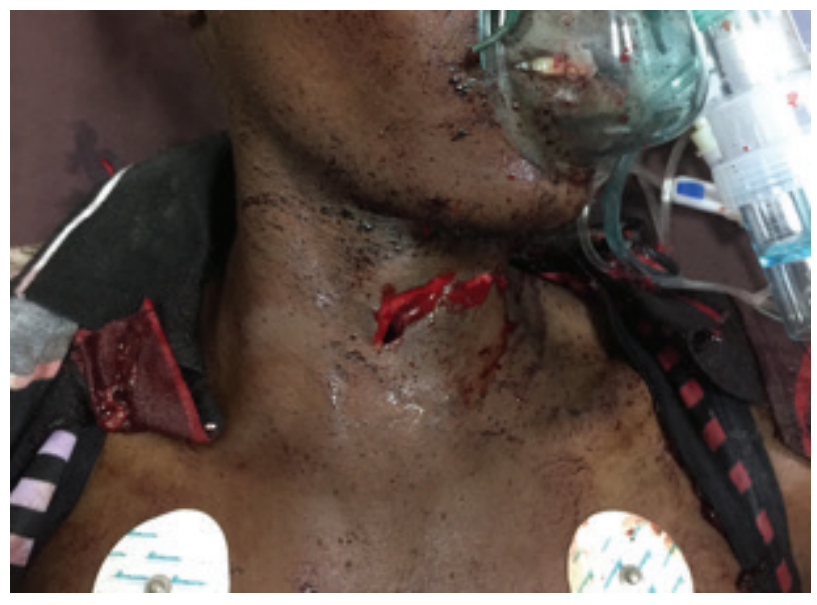

Figure 1: First application

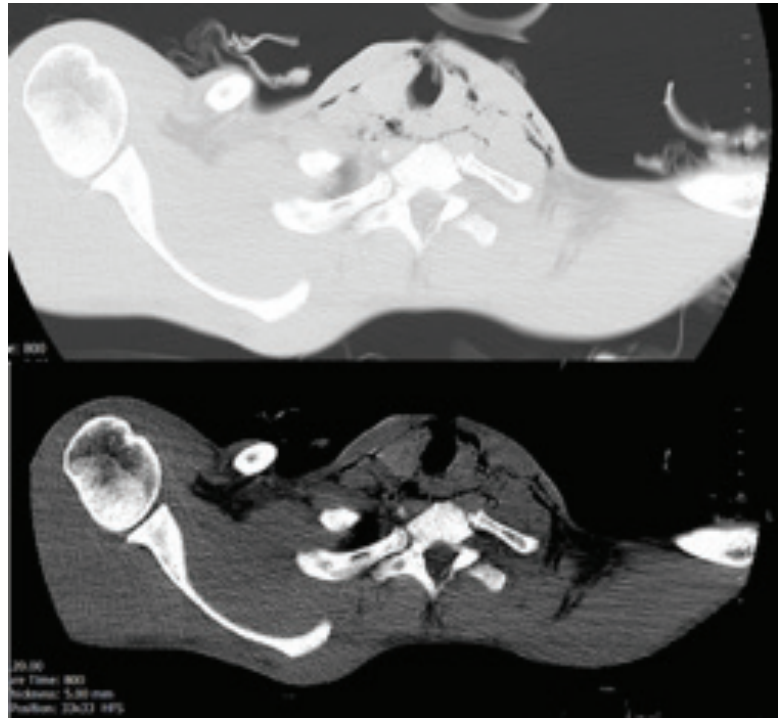

Figure 2: Thorax CT scans

were sutured individually by using 3-0 polypropylene sutures (Figure 3). It was observed that the left vena jugularis interna was damaged during bleeding control and proximal-distal end were connected. Damaged thyroid tissue was repaired and the operation was terminated without any complications. The patient was discharged after 2 days of intensive care and 2 days of follow-up.

\section{Discussion}

Since the cervical trachea has a very superficial structure, mainly, (75-80\%) cervical part of the trachea is affected in penetrating tracheal injuries (5). Such penetrating injuries affecting the mediastinal area of the trachea can also affect large vascular structures at the same time and this will result in frequent fatalities at the occasion (5). There were penetrating injuries at the edge of isthmus in cervical region of the trachea, simultaneous with major vascular injury and thyroid organ damage. If an obvious tracheal injury is not noticed with a 


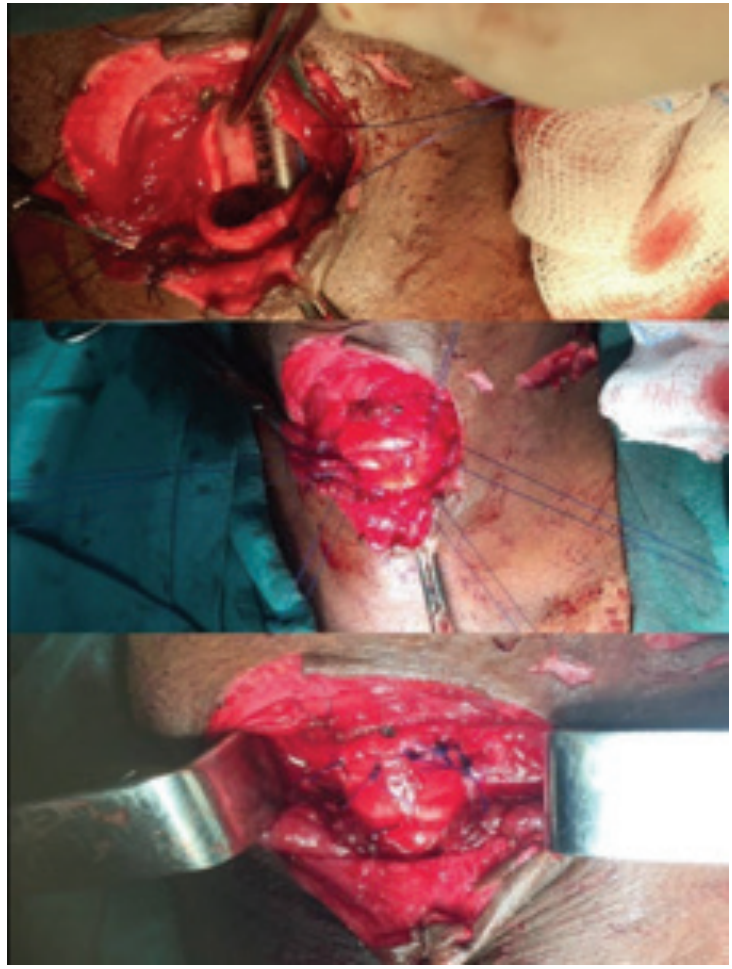

Figure 3: Operation pictures

sufficient anamnesis, physical examination and radiological findings in these patients, bronchoscopy must be performed under the appropriate circumstances. Conditions on when, and to whom the bronchoscope should be performed are controversial (4). It should be kept in mind that small penetrating lesions may not be symptomatic and difficult to detect radiologically. We detected cervical tracheal injury in our physical examination, that's because we applied surgical treatment first. The most common physical examination findings in penetrating traumatic tracheal injuries are shortness of breath, hoarseness, respiratory failure, subcutaneous emphysema, hemoptysis, if there is a skin defect air leakage from skin defect and prolonged air leak in patients with chest drain (5). In our case, partial subcutaneous emphysema, hoarseness and air leak at the incision site were present. The crucial thing is surgical intervention of the injury as soon as possible after resolving life-threatening traumatic problems in complicating penetrating injuries. The principle of surgical repair is debridement of tracheal ends and anastomosis of every tip with each other by using non-absorbable sutures (5). Also, non-absorbable polypropylene suture material can be used for anastomosis after debridement in trachea and the cricoid area. The choice of incision is important according to the localization of the injury; low cervical collar incision will be appropriate for $1 / 3$ proximal injuries of the trachea. In our case, the skin incision on the cervical trachea for penetrating injury was sufficient in the process. Injury was in the proximal trachea, therefore for the assessment of vocal cord paralysis, and hyoid release maneuvers in order to reduce anastomotic tension, operation was performed with an otorhinolaryngologist.

\section{Conclusion}

As a result, mortality and morbidity rates of penetrating tracheal injuries higher. Also surprise major artery cuts may also accompany the injury. For this reason, physical examination, radiological findings and bronchoscopy should be performedin early stages for differential diagnosis and should the most appropriate treatment choice prefer for reduce high risks.

\section{Ethics}

Informed Consent: A consent form was completed by all participants.

Peer-review: Externally and internally peer-reviewed.

\section{Authorship Contributions}

Surgical and Medical Practices: H.F.S., H.D., M.Y.Z., Concept: H.F.S., H.D., M.Y.Z., Design: H.F.S., H.D., M.Y.Z., Data Collection or Processing: H.F.S., H.D., M.Y.Z., Analysis or Interpretation: H.F.S., H.D., M.Y.Z., Literature Search: H.F.S., H.D., M.Y.Z., Writing: H.F.S., H.D., M.Y.Z.

Conflict of Interest: No conflict of interest was declared by the authors.

Financial Disclosure: The authors declared that this study received no financial support.

\section{References}

1. Miñambres E, González-Castro A, Burón J, et al. Management of postintubation tracheobronchial rupture: our experience and a review of the literature. Eur J Emerg Med. 2007;14:177-179.

2. Hood RM, Sloan HE . Injuries of the trachea and major bronchi. In Hood Boyd and Culliford eds. Thoracic Trauma. Philadelphia, W.B. Saunders Company. 1989; p. 245-266.

3. Bertelsen $S$, Howitz $P$. Injuries of the trachea and bronchi. Thorax,1972;27:188-194.

4. Wu CY, Chen TP, Liu YH, et al. Successful treatment of complicated tracheobronchial rupture using primary surgical repair. Chang Gung Med J. 2005;28:662-667.

5. Özdülger A. Trakeobronşiyal Yaralanmalar. Toraks Cerrahisi Bülteni 2010;1:45-54. 